\title{
Nutrition and fertilization management of embryo cultured Makapuno Tall (ECMAKT) seedlings
}

\author{
M.B. Areza-Ubaldo ${ }^{1}$, S.S. Magat $^{2}$, E.P. Rillo ${ }^{3}$, and M.I. Secretaria ${ }^{4}$
}

\begin{abstract}
A two-year nursery study on ECMAKT coconut seedlings was conducted at the Philippine Coconut Authority - Albay Research Center, Guinobatan, Albay to know the effects of applying different rates of complete fertilizer (14-14-14 fortified with micronutrients) and a foliar fertilizer on the vegetative growth and leaf nutrient status of ECMAKT seedlings.

The application of complete NPK fertilizer (14-14-14) at 6-9 g/seedling significantly produced taller seedlings with bigger girth size and more number of living fronds from 2 to 12 months from initial fertilization. The applied rates of complete fertilizer (6-9 g 14-1414/seedling) on ECMAKT seedlings indicates that the levels of nutrient application (fertilization) is significantly much lower than that of the average rates used in growing ordinary seednuts (seedlings attached to unhusked nuts) in the nursery. The application of foliar fertilizer was ineffective even over the unfertilized ECMAKT seedlings.

The better growth of ECMAKT seedlings in terms of their girth, plant height and total living fronds produced were significantly associated with higher levels of leaf $\mathrm{K}, \mathrm{Cl}$, and $\mathrm{Mn}$, and lower leaf $\mathrm{Na}$, but with likely adequate leaf $\mathrm{P}, \mathrm{Mg}, \mathrm{S}, \mathrm{B}, \mathrm{Zn}, \mathrm{Cu}$ and $\mathrm{Fe}$ based from leaf number 3 (12 month old ECMAKT seedling).

The study clearly indicates the necessity of applying inorganic fertilizer i.e. complete fertilizer (14-14-14 fortified with micronutrients) at the moderate rates of 6-9 g/seedling during the nursery stage for proper nutrition and fertilization management to ensure healthy and good quality ECMAKT planting material.
\end{abstract}

Key words: Embryo cultured Makapuno Tall (ECMAKT) coconut, NPK compound fertilizer, foliar fertilizer, $\mathrm{K}$ nutrient, $\mathrm{Cl}$ nutrient, micronutrients.

\footnotetext{
${ }^{1}$ Sc. Research Specialist II, PCA-Albay Research Center, Guinobatan, Albay, e-mail address: mbbareza@globalink.ph

${ }^{2}$ Manager, Agricultural Research Management Dept, \& Scientist IV, PCA-Diliman, Quezon City, e-mail address: ssmagat@ pacific.net.ph or sev_magat@yahoo.com

${ }^{3}$ Division Chief III and Scientist IV, PCA-Albay Research Center, Guinobatan, Albay, e-mail address: eprillo@globalink.ph or indayrillo@yahoo.com

${ }^{4}$ Sc. Research Specialist II \& Scientist I, PCA-Davao Research Center, Bago Oshiro, Davao City, e-mail address: pcaasd@pldtdsl.net or milsecretaria@yahoo.com
} 


\section{Introduction}

In coconut, in-vitro culture had been developed as a tool to rescue the embryo of Makapuno Tall (MAKT) coconut in the Philippines (Rillo, 1995). The technique has been successfully done to produce $75-95 \%$ MAKT bearing palms by the Tissue Culture Division, PCA-Albay Research Center, Guinobatan, Albay.

Before the ECMAKT seedlings are field planted, they have to be established first in the screen house for about 8 months. An ECMAKT seedling is supplied with nutrients (food) from its growth medium in vitro unlike the ordinary seedlings which obtain its food from the haustorium for the first 4 months and from the inorganic fertilizers applied to the seedling during its nursery stage.

The growth medium used, known as Eeuwens (Y3) media formulation provides several macro- and micro-nutrients and a carbohydrate source, usually sucrose, to replace the carbon which the plant normally fixes from the atmosphere by photosynthesis (Rillo, 1995). This growth medium is being consumed by the germinating embryo from incubation time up to its transfer to plastic bags at the screen house. Once the seedlings are transplanted in polyethylene bags at the screen house, they are supplied with minimal nutrients using diluted foliar fertilizer applied weekly. At the Philippine Coconut Authority-Davao Research Center (PCA-DRC) Makapuno nursery, it has been observed that the growth of ECMAKT seedlings have been quite retarded, exhibiting yellowish to light colored leaves, under this fertilizer management.

According to PCA recommendation (The Coconut Committee, 1993; Magat, 1999), coconut seedlings are supplied with nutrients from nitrogen $(\mathrm{N})$ and chlorine $(\mathrm{Cl})$ containing fertilizers (ammonium sulfate and $\mathrm{NaCl}$ or $\mathrm{KCl}$ ) for their normal growth during nursery stage at 2 and 5 months from polybagging. Since ECMAKT seedlings potted in polybags with $100 \%$ sand at the second month and 50:50\% sand and soil medium on the fifth month during their nursery period, are supplied only with diluted foliar fertilizer, it is possible that the embryo cultured MAKT seedlings may not have all the necessary nutrients needed for normal growth, as well as the proper concentration and amounts of these nutrients.

The present study reports the effects of different rates of inorganic fertilizer (14-14-14), inorganic granulated and foliar fertilizers on the vegetative growth. This study was conducted at PCA-Albay Research Center, Guinobatan, Albay for period of two years.

\section{Materials and methods}

The experimental materials used were 4 month-old ECMAKT seedlings produced in the laboratory. At this stage, the seedlings have 3-4 expanded leaves and with profuse secondary and tertiary roots.

ECMAKT seedlings were taken out from the laboratory and hardened in the screen house for 1 week. After the desired period, these were pottedout in small polybags (7"x11") containings $100 \%$ sterilized sand grits (Rillo and Paloma, 1992) and incubated in the screen house (SH) for 2 months without any fertilizer application.

As a preliminary trial, only treatments FT0, FT1 and FT2 (Table 1) were investigated and seedlings were incubated under screen house condition. Fertilizer treatments (replicated 3 times, with 9 seedlings/replicate) were applied starting on the $2^{\text {nd }}$ month of establishment. Seven days after fertilizer application, all the seedlings treated with FT2 (45 g complete fertilizer) died due to excessive fertilizer applied (nutrient rates based on the PCA's general nursery recommendation). Thus, the treatments were modified in succeeding formal experimental work.

For the follow-up trial, 4 month-old ECMAKT seedlings with 3-4 expanded leaves and profuse roots were again produced in the laboratory prior to potting-out. The protocol developed at PCA-ARC (Rillo and Paloma, 1992) for the ex vitro establishment of ECMAKT 
seedlings was used. In the PCA-ARC protocol, ECMAKT seedlings in the screen house were fertilized with a pinch of ammonium sulfate equivalent to $2 \mathrm{~g} / \mathrm{seedling}$ per small polybag at weekly interval. The amount was doubled during the nursery stage. The amount of ammonium sulfate used in the PCA-ARC protocol served as the basis for the modification made on the rate of complete fertilizer treatment used in this study. Table 2 shows the modified fertilizer treatments used in the formal experiment.

ECMAKT seedlings were transferred in bigger polybags (12"x12") 5 months after the first fertilizer application.

Data on vegetative growth characters (girth size, plant height, leaf production and total living fronds) were recorded every 2 months for 12 months.

At the last data gathering, leaf samples from ECMAKT seedlings (leaf frond number 3) were collected, dried for 4 hours (at temperature not $>75^{\circ} \mathrm{C}$ ) prior to submission to the leaf analysis laboratory at the Plant Tissue Analysis Laboratory, PCA-Central Office, Quezon City. Leaf samples were analyzed for contents of macro- and micronutrients.

Data on vegetative growth characters and leaf nutrient level were analyzed using the Analysis of Variance (ANOVA), F- test and the Duncan's Multiple Range Test (DMRT) for the comparison of significant treatment means.

\section{Results and discussion}

\section{Effect on the vegetative growth of seedlings}

Based on the statistical analyses of the vegetative growth characters of ECMAKT seedlings, there were significant differences among the fertilizer treatments in terms of girth size and plant height 2 to 12 months after fertilizer application, and in terms of total live fronds 4,8 to 12 months after fertilizer application (Tables 3 and 4).

The embryo cultured Makapuno seedlings fertilized with a total of $7.5 \mathrm{~g}$ of 14-14-14 complete fertilizer (FT3) for the whole duration of nursery stage (12 months) consistently gave the biggest girth size, tallest plants and highest total number of living fronds from 2 to 12 months after the treatment (Figs. 1a-c).

The application of 14-14-14 (fortified with micronutrients) at moderate rates of 6-9 $\mathrm{g} /$ seedling showed the best vegetative growth of the ECMAKT seedlings. On the other hand, the application of foliar fertilizer was not effective even over the unfertilized ECMAKT seedlings as manifested in their inferior vegetative growth characters.

Comparing the present rates of nutrients from 14-14-14 fertilizer supplied to the ECMAKT seedlings with that of the general or average fertilizer for ordinary coconut seedling (earlier found to be very high and excessive), showed that for ECMAKT seedlings, the levels of nutrient application (fertilization) is significantly much lower (Table 5) than that of the average rates used in growing ordinary seednuts (seedlings with attached unhusked nuts) in the nursery (Table 6).

\section{Effect on the leaf nutrient levels of ECMAKT seedlings}

Results of the statistical analyses of leaf nutrient levels of macro and micronutrients from leaf rank no. 3 showed no significant treatment effect on leaf N, P, Ca, B, Zn, and Cu (Table 8). Leaf dry matter analyses showed that, generally leaf $\mathrm{N}, \mathrm{B}$, and $\mathrm{Cu}$ were lower than the normal (adequate) levels for all the treatments (Table 7).

On the other hand, significant effect of fertilizer treatments on leaf $\mathrm{K}, \mathrm{Mg}, \mathrm{Na}, \mathrm{Cl}, \mathrm{S}$, $\mathrm{Mn}$, and $\mathrm{Fe}$ was observed. The treatments with complete fertilizer (FT2 to FT4) increased leaf 
Table 1. Initial fertilizer grades and rates of the fertilizer treatments (preliminary study)

\begin{tabular}{|c|c|c|c|c|c|}
\hline $\begin{array}{c}\text { Growth stage of ECMAKT } \\
\text { seedling in the screen house }\end{array}$ & $\begin{array}{c}\text { FT0 } \\
\text { Control }\end{array}$ & $\begin{array}{c}\text { FT1 } \\
\text { Foliar fert. }\end{array}$ & $\begin{array}{c}\text { FT2 } \\
14-14-14^{3} \\
\text { (g/seedling) }\end{array}$ & $\begin{array}{c}\text { F3 } \\
14-14-14 \\
\text { (g/seedling) }\end{array}$ & $\begin{array}{c}\text { FT4 } \\
14-14-14 \\
(\mathrm{~g} / \text { seedling })\end{array}$ \\
\hline 2 months & 0 & $2 \mathrm{~g} / 800 \mathrm{ml}^{2}$ & 45 & 90 & 135 \\
\hline 4 months & 0 & - do- & 90 & 180 & 270 \\
\hline Total & 0 & & 135 & 270 & 405 \\
\hline
\end{tabular}

${ }^{1}$ No fertilizer; nutrient supplied by potting mix; ${ }^{2}$ Foliar fertilizer 'Crop Giant' 15-15-30+M.E. applied at $2 \mathrm{~g} / 800 \mathrm{ml}$ every 10 days interval (standard recommendation, st); ${ }^{3}$ Complete commercial fertilizer used: ATLAS Perfect GRO 1414-14 , with $11.7 \% \mathrm{Cl}, 25.2 \% \mathrm{~S}, \quad 0.61 \% \mathrm{CaO}, 0.30 \% \mathrm{Mg}, 47.1 \mathrm{ppm} \mathrm{B}, 31.7 \mathrm{ppm} \mathrm{Zn}$, nil ppm Cu, $32.5 \mathrm{ppm} \mathrm{Mn}$ and $1,761 \mathrm{ppm} F e$ (as analyzed by the Plant Tissue Analysis Laboratory, Plant \& Soil Division, PCA-Diliman, Quezon City)

Table 2. Modified fertilizer treatments of ECMAKT seedlings grown in the screen house and nursery periods

\begin{tabular}{|l|c|c|c|c|c|}
\hline $\begin{array}{l}\text { Growth stage of ECMAKT } \\
\text { seedling in the screen } \\
\text { house }\end{array}$ & $\begin{array}{c}\text { FT0 } \\
\text { Control }\end{array}$ & $\begin{array}{c}\text { FT1 } \\
\text { Foliar fert. }\end{array}$ & $\begin{array}{c}\text { FT2 } \\
14-14-14^{3} \\
(\mathrm{~g} / \text { seedling) }\end{array}$ & $\begin{array}{c}\text { FT3 } \\
\text { (g/seedling) }\end{array}$ & $\begin{array}{c}\text { FT4 } \\
\text { (g/seedling) }\end{array}$ \\
\hline At 2 months & 0 & $2 \mathrm{~g} / 800 \mathrm{ml}^{2}$ & 2 & 2.5 & 3 \\
\hline $\begin{array}{l}\text { At 4 months up to nursery } \\
\text { stage }\end{array}$ & 0 & $2 \mathrm{~g} / 800 \mathrm{ml}$ & 4 & 5.0 & 6 \\
\hline \multicolumn{1}{|c|}{ Total } & & 6 & 7.5 & 9 \\
\hline
\end{tabular}

${ }^{1}$ No fertilizer; nutrient supplied by potting mix; ${ }^{2}$ Foliar fertilizer 'Crop Giant' 15-15-30+M.E. applied at $2 \mathrm{~g} / 800 \mathrm{ml}$ every 10 days interval (standard recommendation, st); ${ }^{3}$ Complete commercial fertilizer used: ATLAS Perfect GRO 14-14-14, with $11.7 \% \mathrm{Cl}, 25.2 \% \mathrm{~S}, 0.61 \% \mathrm{CaO}, 0.30 \% \mathrm{Mg}, 47.1 \mathrm{ppm} \mathrm{B}, 31.7 \mathrm{ppm} \mathrm{Zn}$, nil ppm Cu, $32.5 \mathrm{ppm} \mathrm{Mn}$ and 1,761 ppm Fe (as nalyzed by the Plant Tissue Analysis Laboratory, Plant \& Soil Division, PCA-Diliman, Quezon City)

Table 3. Effect of different fertilizer treatments on the growth characters of embryo cultured Makapuno seedlings at different growth stages (months), PCA-Albay Research Center, Banao, Guinobatan, Albay, 2003

\begin{tabular}{|c|c|c|c|c|c|c|c|c|}
\hline $\begin{array}{l}\text { Growth } \\
\text { parameter }\end{array}$ & $\begin{array}{c}\text { Fertilizer } \\
\text { Treatment }\end{array}$ & Initial $^{\#}$ & $\begin{array}{c}2 \\
\text { mo.. }\end{array}$ & $\begin{array}{c}4 \\
\text { mo. }\end{array}$ & $\begin{array}{c}6 \\
\text { mo. }\end{array}$ & $\begin{array}{c}8 \\
\text { mo. }\end{array}$ & $\begin{array}{l}10 \\
\text { mo. }\end{array}$ & $\begin{array}{c}12 \\
\text { mo. }\end{array}$ \\
\hline \multirow{5}{*}{ Girth size $(\mathrm{cm})$} & FT0 & 3.22 & $3.40 \mathrm{~b}$ & $3.54 \mathrm{c}$ & $3.70 \mathrm{bc}$ & $3.82 \mathrm{c}$ & $3.78 \mathrm{c}$ & $3.87 \mathrm{c}$ \\
\hline & FT1 & 3.36 & $3.64 \mathrm{~b}$ & $3.90 \mathrm{bc}$ & $3.84 \mathrm{~b}$ & $3.97 \mathrm{bc}$ & $3.95 \mathrm{c}$ & $4.16 \mathrm{bc}$ \\
\hline & FT2 & 3.30 & $3.52 \mathrm{~b}$ & $3.80 \mathrm{bc}$ & $3.70 \mathrm{bc}$ & $3.88 \mathrm{c}$ & $3.94 \mathrm{c}$ & $4.16 \mathrm{bc}$ \\
\hline & FT3 & 3.37 & $3.94 \mathrm{a}$ & $4.44 \mathrm{a}$ & $4.44 \mathrm{a}$ & $4.75 \mathrm{a}$ & $4.77 \mathrm{a}$ & $4.96 \mathrm{a}$ \\
\hline & FT4 & 3.13 & $3.59 \mathrm{~b}$ & $4.08 \mathrm{~b}$ & $3.44 \mathrm{c}$ & $4.20 \mathrm{~b}$ & $4.34 \mathrm{~b}$ & $4.43 \mathrm{~b}$ \\
\hline \multirow{5}{*}{$\begin{array}{l}\text { Plant height } \\
(\mathrm{cm})\end{array}$} & FT0 & 36.02 & $38.97 \mathrm{~b}$ & $39.80 \mathrm{~b}$ & $35.93 \mathrm{c}$ & $39.59 \mathrm{~b}$ & $41.62 \mathrm{~b}$ & $44.04 \mathrm{c}$ \\
\hline & FT1 & 34.87 & $40.86 \mathrm{~b}$ & $45.88 \mathrm{~b}$ & $44.86 \mathrm{~b}$ & $46.46 \mathrm{~b}$ & $47.56 \mathrm{~b}$ & $49.54 \mathrm{bc}$ \\
\hline & FT2 & 34.88 & $40.54 \mathrm{~b}$ & $44.45 \mathrm{~b}$ & $46.23 \mathrm{~b}$ & $46.06 \mathrm{~b}$ & $47.48 \mathrm{~b}$ & $49.24 \mathrm{bc}$ \\
\hline & FT3 & 37.58 & $46.91 \mathrm{a}$ & $53.38 \mathrm{a}$ & $56.50 \mathrm{a}$ & $58.79 \mathrm{a}$ & $58.61 \mathrm{a}$ & $62.34 \mathrm{a}$ \\
\hline & FT4 & 34.75 & $41.79 \mathrm{~b}$ & $45.87 \mathrm{~b}$ & $46.72 \mathrm{~b}$ & $45.36 \mathrm{~b}$ & $47.88 \mathrm{~b}$ & $52.29 \mathrm{a}$ \\
\hline \multirow{5}{*}{$\begin{array}{l}\text { Total living } \\
\text { fronds \# }\end{array}$} & FT0 & 4.29 & 4.38 & $3.97 \mathrm{~b}$ & 4.12 & $2.95 \mathrm{~b}$ & $3.57 \mathrm{c}$ & $4.36 \mathrm{~d}$ \\
\hline & FT1 & 4.48 & 4.89 & $3.34 \mathrm{~b}$ & 4.06 & $3.18 \mathrm{~b}$ & $3.86 \mathrm{bc}$ & $4.75 \mathrm{c}$ \\
\hline & FT2 & 4.48 & 4.34 & $3.73 \mathrm{~b}$ & 4.17 & $3.33 \mathrm{~b}$ & $4.09 \mathrm{~b}$ & $4.71 \mathrm{c}$ \\
\hline & FT3 & 4.37 & 5.07 & $4.67 \mathrm{a}$ & 4.07 & $4.33 \mathrm{a}$ & $5.00 \mathrm{a}$ & $5.82 \mathrm{a}$ \\
\hline & FT4 & 4.56 & 5.14 & $3.88 \mathrm{~b}$ & 3.56 & $3.96 \mathrm{a}$ & $4.81 \mathrm{a}$ & $5.20 \mathrm{~b}$ \\
\hline
\end{tabular}

Before fertilizer treatment

Treatment means with the same letter(s) are not significantly different from each other at 5\% level (Duncan's Multiple Range Test [DMRT]). 
a
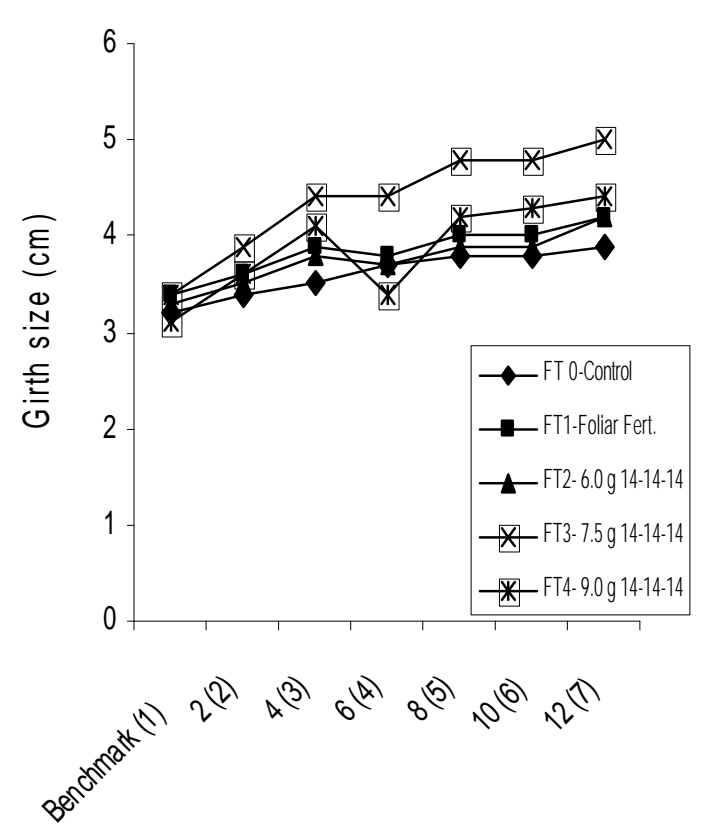

Months from initial fertilizer application (growth stages) b

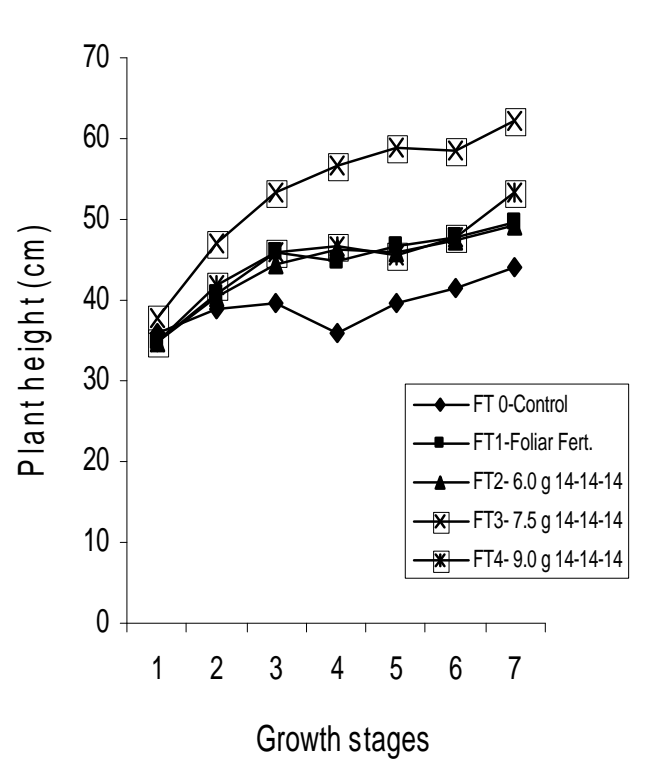

C

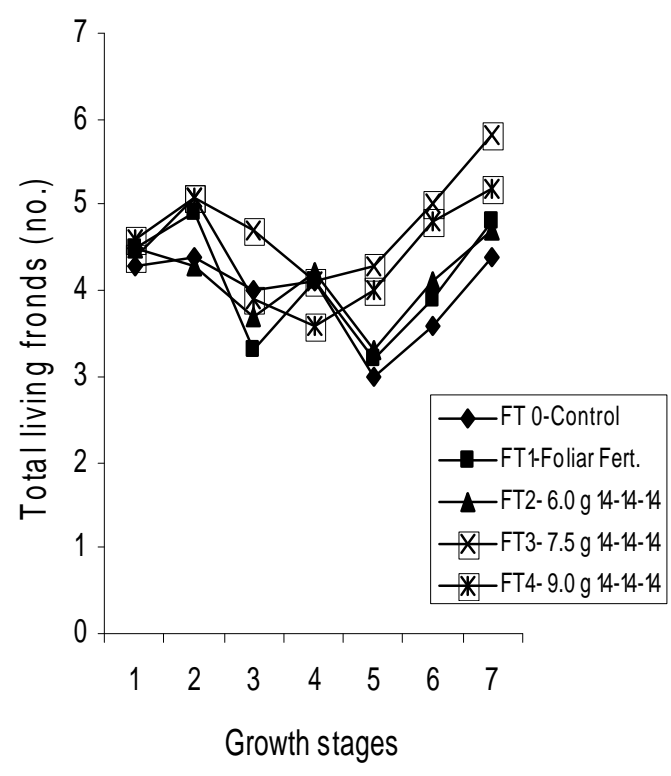

Fig. 1. Effect of fertilizer treatments on the (a) girth size, (b) plant height and (c) total number of living fronds of ECMAKT seedlings at different growth stages, PCA-ARC, Albay, 2003 
$\mathrm{K}$ levels but decreased the level of Mg (likely due to the antagonistic effect of high level of $\mathrm{K}$ ), $\mathrm{Na}$, $\mathrm{Cl}, \mathrm{S}, \mathrm{Mn}, \mathrm{Cu}$, and $\mathrm{Fe}$. It could be noted that the levels of $\mathrm{N}, \mathrm{Cl}, \mathrm{B}, \mathrm{Mn}$, and $\mathrm{Cu}$ for all the treatments are likely to be below the critical levels for these nutrients based on leaf rank no. 3 or 4: N, 1.95\% (Magat, 1991); Cl, 0.65\% (Magat, 1991); B, 13 ppm; Mn, 130 ppm; and $\mathrm{Cu}, 18.5$ ppm (Friend, 1975 cited by Magat, 1999). However, the low nutrient concentration in the reference leaves may also be attributed to the well-known "dilution effect" in plant growth in which nutrients are distributed to larger volume of biomass produced. Moreover, it was also noted that the levels of leaf $\mathrm{P}$ and $\mathrm{Zn}$ were at average levels for normal growth. The role of phosphorus serves as a component of nucleic acid (genetic material), of ADP and ATP (which are vehicles of energy transfer in and amongst cells), and of several coenzymes (which activate biochemical processes). Zinc participates in chlorophyll formation, and also activates many enzymes (Earth and Table, 2002).

The good vegetative growth, therefore, of embryo cultured MAKT seedlings from FT3 (7.5 $\mathrm{g} /$ seedling 14-14-14) treatment was very likely attributed to the adequate levels of leaf $\mathrm{K}, \mathrm{Ca}, \mathrm{Cl}$ and $\mathrm{Mn}$ (leaf 3). Potassium is known as an essential constituent for plant growth. It is required by plants for photosynthesis, osmotic regulation and the activation of enzyme systems. Calcium is an essential constituent of the leaves; it is an essential part of plant cell wall structure, provides for normal transport and retention of other elements and strength in the plant. Chlorine is necessary for osmosis and ionic balance; it also plays a role in photosynthesis. While manganese activates some important enzymes involved in chlorophyll formation (Earth and Table, 2002).

Moreover, growth of seedlings like the total living fronds appears better at higher leaf $\mathrm{K} /$ leaf $\mathrm{Ca}+\mathrm{Mg}+\mathrm{Na}$ ratios $(1.90-2.0)$ or at lower leaf $\mathrm{K}+\mathrm{Ca}+\mathrm{Mg}+\mathrm{Na} / \mathrm{leaf} \mathrm{Cl}$ ratios $(5.56$ - 6.74), indicated in Table 9. These observations suggest the importance of very adequate $\mathrm{K}$ of the developing ECMAKT seedlings, as well as the anion nutrient $\mathrm{Cl}$ in maintaining a lower ratio of cations and anion $\mathrm{Cl}$ in balanced seedling nutrition, desirable for its better growth.

These results clearly showed that ECMAKT seedlings responded positively to the application of inorganic fertilizer (14-14-14), as a result of its capability to supply significant amounts of K, $\mathrm{Cl}$ and $\mathrm{Mn}$ beneficial to the growth of the ECMAKT seedlings. Furthermore, the improvement in the vegetative growth characters particularly on the girth size under the treatments with complete fertilizer (with significant amounts of $\mathrm{Cl}$ nutrient) could be well explained by the significant beneficial levels of $\mathrm{Cl}$ in these treatments. This result supports earlier findings that $\mathrm{Cl}$ application significantly increased the growth of girth of seedlings at nursery stage (Magat et al., 1977; Oguis et al., 1979; Magat and Prudente, 1974 as cited in Maravilla, 1986). Moreover, leaf $\mathrm{Cl}$ is almost always positively correlated with the girth size of developing seedlings and young palms (Magat et al., 1977; Secretaria, 2003). In this study, the leaf $\mathrm{Cl}$ of seedlings with better growth ranged from 0.40 $0.44 \% \mathrm{Cl}$ and $1.60-1.90 \% \mathrm{~K}$ of leaf 3 .

It strongly appears that there is still a need to increase the levels of leaf $\mathrm{Mn}$ and $\mathrm{Cu}$ to achieve optimum seedling nutrition, hence another inorganic compound ready-to-apply fertilizers as indicated in the Table 10. These supply higher concentration of the mentioned micronutrients and thus, may be considered as an alternative to ATLAS Perfect GRO (14-14-14 fertilizer grade) used in this experiment.

\section{Conclusion}

Based on the results of this nursery study, it can be concluded that ECMAKT seedlings responded positively to the application of inorganic fertilizer (14-14-14 fortified with 
Table 4. Results of statistical analysis of growth parameters of ECMAKT seedlings as affected by different fertilizer treatments at different growth stages, PCA-ARC,

Guinobatan, Albay, 2003

\begin{tabular}{|l|c|c|c|c|c|c|c|}
\hline \multicolumn{9}{|c|}{ Statistical significance } \\
\hline Growth Stage (months) & Initial & 2 & 4 & 6 & 8 & 10 & 12 \\
\hline Growth parameters: & & & & & & & \\
\hline$\bullet \quad$ Girth size & $\mathrm{ns}$ & $*$ & $* *$ & $* *$ & $* *$ & $* *$ & $* *$ \\
\hline$\bullet \quad$ Plant & $\mathrm{ns}$ & $*$ & $*$ & $* *$ & $* *$ & $* *$ & $* *$ \\
\hline$\bullet \quad$ Total living fronds height & $\mathrm{ns}$ & $\mathrm{ns}$ & $*$ & $\mathrm{~ns}$ & $* *$ & $* *$ & $* *$ \\
\hline
\end{tabular}

Ns - Treatment effect is not significant; * Significant at $5 \%$ level; ** Significant at $1 \%$ level

Table 5. Main nutrients contents of complete NPK fertilizer treatments (FT2, FT3 and FT4) recommended for ECMAKT seedlings as grown in the screen house to the nursery

\begin{tabular}{|c|c|c|c|c|}
\hline \multirow{2}{*}{ Total amount of 14-14-14 fertilizer applied } & \multicolumn{4}{|c|}{ Levels of nutrient applied (g) } \\
\cline { 2 - 5 } & $\mathrm{N}$ & $\mathrm{P}_{2} \mathrm{O}_{5}$ & $\mathrm{~K}_{2} \mathrm{O}$ & $\mathrm{Cl}$ \\
\hline @ 6 g/seedling (FT2) & 0.84 & 0.84 & 0.84 & 0.70 \\
\hline @ 7.5 g/seedling (FT3) & 1.05 & 1.05 & 1.05 & 0.88 \\
\hline @ 9 g/seedling (FT4) & 1.26 & 1.26 & 1.26 & 1.05 \\
\hline
\end{tabular}

Table 6. PCA general or average fertilizer rates for nursery seedlings grown from seednuts

\begin{tabular}{|c|c|c|c|c|}
\hline \multicolumn{2}{|l|}{$\begin{array}{c}{\left[\mathrm{NH}_{4}\right]_{2} \mathrm{SO}_{4}} \\
(21-0-0)\end{array}$} & \multicolumn{3}{|l|}{$\begin{array}{l}\text { Plus KCl } \\
(0-0-60)\end{array}$} \\
\hline & $\begin{array}{l}\text { Amount of } \mathrm{N} \\
\text { supplied: }\end{array}$ & & $\begin{array}{l}\text { Amount of } \mathrm{K}_{2} \mathrm{O} \\
\text { supplied: }\end{array}$ & $\begin{array}{l}\text { Amount of } \mathrm{Cl} \\
\text { supplied: }\end{array}$ \\
\hline @ $20 \mathrm{~g} /$ seedling & $4 \mathrm{~g}$ & $25 \mathrm{~g} /$ seedling & $15 \mathrm{~g}$ & $\begin{array}{l}11 \mathrm{~g} \text { (applied at } 2 \\
\text { months from } \\
\text { polybagging) }\end{array}$ \\
\hline @ $40 \mathrm{~g} /$ seedling & $8 \mathrm{~g}$ & $45 \mathrm{~g} /$ seedling & $27 \mathrm{~g}$ & $\begin{array}{l}19.8 \mathrm{~g} \text { (applied at } \\
5 \text { months from } \\
\text { polybagging) }\end{array}$ \\
\hline
\end{tabular}


Table 7. Leaf nutrient levels (at leaf rank no. 3) of embryo cultured Makapuno tall seedlings treated with foliar and different rates of inorganic fertilizer (14-14-14) treatments at 12 months, PCA-ARC, 2003

\begin{tabular}{|c|c|c|c|c|c|c|c|c|c|c|c|c|c|}
\hline \multirow{2}{*}{ Fertilizer treatment } & \multicolumn{8}{|c|}{ Percent $(\%)$ dry matter } & \multicolumn{5}{|c|}{ mg-kg ${ }^{-1}$ Dry matter } \\
\hline & $\mathrm{N}$ & $\mathrm{P}$ & $\mathrm{K}$ & $\mathrm{Ca}$ & $\mathrm{Mg}$ & $\mathrm{Na}$ & $\mathrm{Cl}$ & $\mathrm{S}$ & B & $\mathrm{Zn}$ & Mn & $\mathrm{Cu}$ & $\mathrm{Fe}$ \\
\hline FT0 & 1.47 & 0.14 & $1.17 \mathrm{c}$ & 0.56 & $0.25 \mathrm{a}$ & $0.31 \mathrm{a}$ & $0.26 \mathrm{~b}$ & $0.18 \mathrm{a}$ & 12.23 & 19.56 & $49.30 \mathrm{bc}$ & 4.13 & $102.87 \mathrm{a}$ \\
\hline FT1 & 1.43 & 0.13 & $1.31 \mathrm{c}$ & 0.50 & $0.22 \mathrm{~b}$ & $0.32 \mathrm{a}$ & $0.24 \mathrm{~b}$ & $0.15 \mathrm{~b}$ & 11.36 & 17.76 & $41.07 \mathrm{c}$ & 4.46 & $63.70 \mathrm{~b}$ \\
\hline FT2 & 1.49 & 0.15 & $1.89 \mathrm{a}$ & 0.53 & $0.20 \mathrm{bc}$ & $0.22 \mathrm{~b}$ & $0.43 \mathrm{a}$ & $0.15 \mathrm{~b}$ & 11.70 & 20.03 & $72.63 \mathrm{ab}$ & 4.50 & $70.47 \mathrm{~b}$ \\
\hline FT3 & 1.38 & 0.13 & $1.63 \mathrm{~b}$ & 0.52 & $0.17 \mathrm{c}$ & $0.17 \mathrm{~b}$ & $0.44 \mathrm{a}$ & $0.12 \mathrm{c}$ & 11.46 & 17.96 & $89.40 \mathrm{a}$ & 3.90 & $71.23 \mathrm{~b}$ \\
\hline FT4 & 1.47 & 0.14 & $1.78 \mathrm{ab}$ & 0.49 & $0.17 \mathrm{c}$ & $0.19 \mathrm{~b}$ & $0.39 \mathrm{a}$ & $0.13 \mathrm{bc}$ & 11.03 & 18.36 & $89.60 \mathrm{a}$ & 4.06 & $74.30 \mathrm{~b}$ \\
\hline $\begin{array}{l}\text { Critical level, Leaf } 4 \\
\text { (Magat, 1988) }\end{array}$ & 1.95 & 0.13 & 1.70 & 0.35 & 0.25 & 0.30 & 0.65 & 0.17 & $(13)^{*}$ & $(18)$ & (130) & $(18.5$ & (90) \\
\hline
\end{tabular}

" Unilever (Friend, 1975); Treatment means with the same letter(s) are not significantly different from each other (DMRT Test)

Table 8. Results of statistical analysis of the macro- and micronutrients obtained from leaf frond 3 of ECMAKT seedlings as affected by different fertilizer treatments

\begin{tabular}{|c|c|c|c|c|c|c|c|c|c|c|c|c|c|}
\hline \multicolumn{9}{|c|}{ Macronutients } & \multicolumn{5}{|c|}{ Micronutrients } \\
\hline & $\mathrm{N}$ & $\mathrm{P}$ & $\mathrm{K}$ & $\mathrm{Ca}$ & $\mathrm{Mg}$ & $\mathrm{Na}$ & $\mathrm{Cl}$ & $\mathrm{S}$ & $\mathrm{B}$ & $\mathrm{Zn}$ & $\mathrm{Mn}$ & $\mathrm{Cu}$ & $\mathrm{Fe}$ \\
\hline Statistical Significance & ns & $\mathrm{Ns}$ & $* *$ & $\mathrm{~ns}$ & $* *$ & $* *$ & $* *$ & $* *$ & ns & ns & $* *$ & ns & $*$ \\
\hline
\end{tabular}

Ns - Treatment effect is not significant; * Significant at 5\% level; ** Significant at $1 \%$ level 
Table 9. Indicative relationship of the different fertilizer treatments, seedling growth and selected leaf (3) nutrient contents ratios of ECMAKT seedlings (12 month-old), PCA-ARC, 2003

\begin{tabular}{|c|c|c|c|}
\hline Treatment & Total living fronds (no.) & $\begin{array}{c}\text { Leaf K/leaf Ca+ Mg }+ \\
\text { Na) nutrient ratio }\end{array}$ & $\begin{array}{c}\text { Leaf K+ Ca+ Mg+Na/ } \\
\text { leaf Cl nutrient ratio }\end{array}$ \\
\hline FT0 & 4.36 & 1.04 & 8.80 \\
\hline FT1 & 4.75 & 1.25 & 9.79 \\
\hline FT2 & 4.71 & 1.98 & 6.60 \\
\hline FT3 & 5.82 & 1.89 & 5.65 \\
\hline FT4 & 5.20 & 2.09 & 6.74 \\
\hline
\end{tabular}

Table 10. Nutrient contents of some locally-available compound fertilizers

\begin{tabular}{|l|c|c|c|}
\hline \multicolumn{1}{|c|}{ Constituent } & $\begin{array}{c}\text { Perfect Gro }^{2} \\
(14-14-14)\end{array}$ & $\begin{array}{c}\text { Topdress }^{1} \\
(17-0-17)\end{array}$ & $\begin{array}{c}\text { Grow More }^{3} \\
(16-16-16)\end{array}$ \\
\hline Total N, \% & $16.0(11.7)^{4}$ & 17.5 & 16.0 \\
Total P $\left(\mathrm{P}_{2} \mathrm{O}_{5}\right), \%$ & $10.8(14.9)$ & 0.70 & 16.0 \\
Total $\mathrm{K}\left(\mathrm{K}_{2} \mathrm{O}\right), \%$ & $15.4(17.1)$ & 17.5 & 16.0 \\
Total $\mathrm{Ca}(\mathrm{CaO}) \%$ & 0.39 & 0.05 \\
Total $\mathrm{Mg}(\mathrm{MgO}), \%$ & $0.31(1.70)$ & 0.16 & 0.10 \\
Total S (S), \% & $25.2(11.2)$ & 16.0 & 0.20 \\
Chloride (Cl) \% & $11.7(11.4)$ & 29.0 & - \\
Sodium (Na), \% & $0.21(0.41)$ & 0.47 & - \\
Zinc (Zn), ppm & $31.7(89.5)$ & 5.10 & 500 \\
Copper $(\mathrm{Cu}), \mathrm{ppm}$ & Trace $(126.6)$ & 2.50 & 500 \\
Manganese (Mn), ppm & $32.5(221.2)$ & 8.9 & 1,000 \\
Iron (Fe), ppm & $1,761(3,488)$ & 489.0 & 200 \\
Boron (B), ppm & $47.7(13.9)$ & 92.8 & 5 \\
Molybdenum (Mo), ppm & - & - & - \\
pH & 6.8 & 6.9 & - \\
Moisture content, \% & 1.36 & 4.04 & \\
\hline
\end{tabular}

Suitable if $\mathrm{P}$ nutrient sufficient

${ }^{2}$ Perfect Gro and Topdress (AFC Corp.) - analyzed by DA-BSWM and PCA laboratories, both at Diliman, Quezon City

${ }^{3}$ Grow More - reported by the manufacturer (Sagrex)

${ }^{4}$ Values in parenthesis refers to PHILPHOS commercial 14-14-14 (fortified with micronutrients) 
micronutrients) in terms of its vegetative growth characters and leaf nutrient levels. The application of 14-14-14 inorganic fertilizer at moderate rate of 6-9 $\mathrm{g} / \mathrm{seedling}$ showed the best growth of seedlings. The application of foliar fertilizer was not effective even over the unfertilized ECMAKT seedlings.

The better growth of seedlings, particularly indicated by its girth size, plant height and number of living fronds were significantly associated with higher levels of leaf $\mathrm{K}, \mathrm{Cl}$ and $\mathrm{Mn}$ and lower leaf $\mathrm{Na}$, but with likely adequate leaf $\mathrm{P}, \mathrm{Mg}, \mathrm{S}, \mathrm{B}, \mathrm{Zn}, \mathrm{Cu}$ and $\mathrm{Fe}$, based from leaf 3 (12 month old ECMAKT seedling). Moreover, proper nutrition management of seedlings very likely requires optimum leaf nutrient ratios: higher leaf $\mathrm{K} / \mathrm{leaf} \mathrm{Ca}+\mathrm{Mg}+\mathrm{Na}(1.85-2.0)$, and lower leaf $\mathrm{K}+\mathrm{Ca}+\mathrm{Mg}+\mathrm{Na} /$ leaf $\mathrm{Cl}(5.5$ - 6.75). This indicates the significance of the cation $\mathrm{K}$ and the anion $\mathrm{Cl}$ nutrients even as early as the seedling development stage of ECMAKT.

The study clearly indicates the necessity of applying inorganic fertilizer i.e. complete fertilizer (14-14-14 fortified with micronutrients) at moderate rates of 6-9 g/seedling during the nursery stage for proper nutrition and fertilization management of ECMAKT seedling. However, the use of same inorganic fertilizer grade (now commercially available) with higher contents of $\mathrm{Mn}$ and $\mathrm{Cu}$ micronutrients should be explored as an alternative fertilizer. This fertilization management practice will ensure healthy and good quality embryo cultured Makapuno seedlings.

\section{Acknowledgement}

The authors wish to express appreciation and gratitude to Mr. Nilo M. Navarro, Laboratory Aide II, for his hard work in the establishment and maintenance of Makapuno embryo cultures in the laboratory, screen house and nursery and for his patience in gathering the data. Thanks are due to the other staff of the Tissue Culture Division of PCA-Albay Research Center for their support in many ways in order to finish this study. We are grateful to Ms. Carmelita D.
Pabustan, Division Chief III, and her staff of the PCA-Plant Tissue Analysis Laboratory, Diliman, Quezon City for the analysis of the leaf samples and the Philippine Coconut Authority for the financial support extended to the project.

\section{References}

Earth and Table 2002. Glossary of Gardening Terms. Plants \& Plant Health-Essential Elements. SmartRiver Communications. $2 \mathrm{p}$.

(www.earthandtable.com/glossary/plants/ essentialelements.html).

Friend, D. 1975. Joint Coconut Research Scheme, 1971-74. The Solomons Islands and Levers Pacific Plantations Propriety Ltd.

Magat, S.S. 1991. Fertilizer recommendation for coconut based on soil and leaf analysis. Phil. J. Cocon. Stud. 16 (2):25-30.

Magat, S.S. 1999. Handbook on fertilizer recommendations for coconut and selected intercrops. Asian and Pacific Coconut Community, Jakarta, Indonesia 106pp.

Magat, S.S., Margate, R.Z. and Prudente, R.L. 1977. Utilization of common salt (sodium chloride) as a fertilizer and for the control of leaf spot disease coconut seedlings. Phil. J. Cocon. Stud. 2 (3):39-45.

Maravilla, J.N. 1986. Nutrition and fertilization of coconut seedlings in polybags. The Phil. J. Cocon. Stud. 11 (1):44-56.

Oguis, L.G., Magat, S.S. and Margate, R.Z. 1979. The effect of chlorine sources and ammonium sulfate on the growth of coconut seedlings. Phil. J. Cocon. Stud. 4 (3): 25-39.

Rillo, E.P. 1995. Embryo culture of Coconut: A laboratory manual. 1995. Tissue Culture Division. PCA-Albay Research Center, Guinobatan, Albay, 42pp. 
Rillo, E.P. and Paloma, M.B.F. 1992. In vitro culture of Makapuno coconut embryos. Cocon.Today 9 (1):90-101.

Secretaria, M.I. 2003. Effects of AZ41 organic foliar fertilizer on the vegetative performance and nutrition of coconut seedlings at PCA-Davao Research Center, Bago Oshiro, Davao City. A terminal/final report submitted to AZ Agric. Products Corporation and PCA-RDEB Management for the 'Efficacy testing of AZ41 on coconut seedlings', $31 \mathrm{pp}$.

The Coconut Committee, 1993. The Philippine Recommends for Coconut. Los Banos, Laguna. PCARRD, PARRFI and PCRDF. 1993. 234 p. (Phil. Recommends Series No. 2-B). 